\title{
Herring Investigations at Plymouth. VI. Winter Herrings Caught off the Sussex Coast and in the Great West Bay during the Years 1924 to 1927.
}

\author{
By
}

E. Ford, A.R.C.Sc.,

Naturalist at the Plymouth Laboratory.

With 2 Figures in the Text.

CONTENTS.

INTRODUCTION

Herrings Caught off the Sussex Coast . . . . . . . . . 26

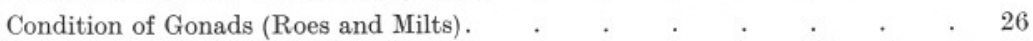

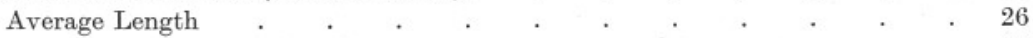

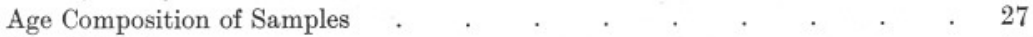

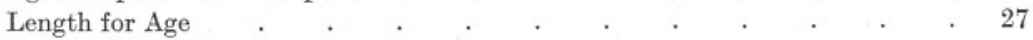

Length at Formation of First Winter-ring . . . . . . . . . $\quad 28$

Growth subsequent to Formation of First Winter-ring . $\quad$. $\quad$. $\quad$. $\quad . \quad 29$

Movements of Shoals _. . . . . . . . . . . . . . $\quad .30$

Racial Considerations $\quad . \quad$. $\quad . \quad$. $\quad . \quad$. . . . . . . 31

Herrings Cadght in the Great West Bay . . . . . . . . . 33

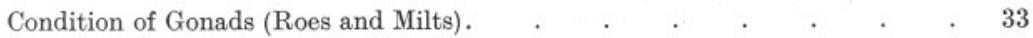

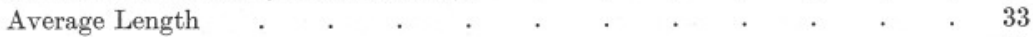

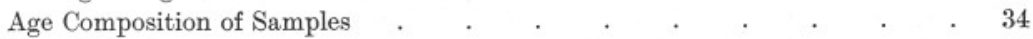

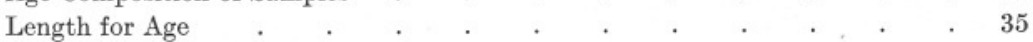

Length at Formation of First Winter-ring . . . . . . . . . $\quad$. 38

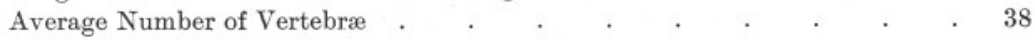

Literature Cited.

TABLES. . . . . . . . . . . . . . . . . . . . $\quad$. 39

\section{INTRODUCTION.}

As explained in Part I of this series of Reports (Ford, 1, p. 238) it was thought that the study of herrings landed at other ports would provide information bearing upon the question of the origin and migrations of the shoals visiting Plymouth during the winter. The examination of the appreciable number of such samples obtained, however, has yielded results which are of interest in themselves, apart from their application 
to the question of the Plymouth fishery. In this paper, an account is given of the study of herrings landed at Hastings and Brighton from off the Sussex coast, and at Brixham from the Great West Bay. It is necessary to point out that the sampling was not specifically designed for such a study, so that due allowance for this fact must be made in drawing conclusions as to the progress of the local fisheries.

I am indebted to the following gentlemen for their kindness in forwarding samples to Plymouth :-

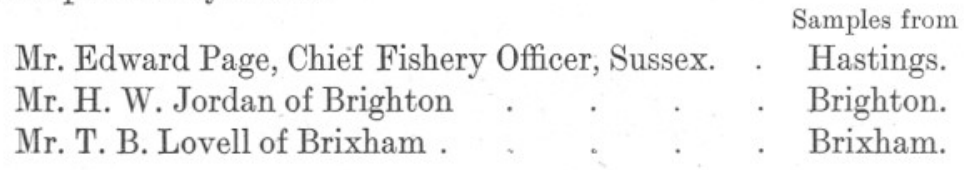

\section{Herrings Caught off the Sussex Coast.}

During the months of October, November, and December, herrings caught in drift or standing nets in local waters by small craft are landed at ports or on beaches along the Sussex coast. A total of 9 samples taken in this area during the seasons 1924 to 1927 was examined, and data collected regarding length, age, growth, sexual condition, and average number of vertebræ.

\section{Condition of Gonads (Roes and Milts).}

The examination of the gonads showed that the samples consisted overwhelmingly of " full " fishes, with occasional ripe, spent or immature individuals. Actual spawning, therefore, would hardly be expected to occur until at least the end of December. The youngest fishes (3-zoned 3-ringed) possessed well-advanced gonads, so that it is reasonable to suppose that first spawning may commonly occur during the third winter of life in the scaled condition.

\section{Average Length.}

The values of the median $\left(Q_{2}\right)$ and quartiles $\left(Q_{1}\right.$ and $\left.Q_{3}\right)$ for each sample are given in Table $\mathrm{I}$ on page 39 . The range in length of the middle $50 \%\left(Q_{3}-Q_{1}\right)$ may again be used as a convenient index of the commonest sizes (cf. Ford, III, p. 287). It is seen that $Q_{1}$ varied from $22.1 \mathrm{~cm}$. to $23.2 \mathrm{~cm}$., and $\mathrm{Q}_{3}$ from $23.8 \mathrm{~cm}$. to $24.7 \mathrm{~cm}$. ; that is to say, fishes of the 22,23 , and $24 \mathrm{~cm}$. groups always comprised at least $50 \%$ of each sample. It was shown in Part III (Ford, 1, p. 287) that the Plymouth winter fishery is centred chiefly upon herrings of the 25, 26, 27 , and $28 \mathrm{~cm}$. groups, so that here on the Sussex coast the fishery is based upon much smaller fishes. 


\section{Age Composition of Samples.}

The estimates of age from scale readings are given in Table II on page 40 in the form of percentages and in graphic form in Fig. 1. It is clear that, throughout, the bulk of a sample was made up of 3-zoned 3-ringed or 4-zoned 4-ringed fishes. This suggests that, in each season, the landings include a considerable proportion of new stock, and, also, that much of the old stock remaining from a previous season either does not subsequently return to the district or evades capture by the local nets.

It will be seen that whereas in 1924, 1925, and 1926, 4-zoned 4-ringed herrings were appreciably more numerous than the 3-zoned 3-ringed ones, in 1927 the reverse was the case, for in a sample taken on November 1st, 1927, at Brighton, $70 \%$ consisted of year-class 1925 . The abundance of herrings of this particular year-class during the winter of 1927 is an interesting observation, for the same phenomenon was observed at Plymouth.

\section{Length for Age.}

In view of the importance of the 3 -zoned and 4-zoned fishes, the average length and individual variation of individuals in these two age-groups are given below :-

\begin{tabular}{|c|c|c|c|c|c|c|c|c|c|c|c|c|}
\hline \multirow{4}{*}{ 3-zoned 3-ringed \{} & $\begin{array}{c}\text { Date. } \\
\text { Dec. 9th } 1924\end{array}$ & $\begin{array}{l}\text { Port of } \\
\text { Landing. } \\
\text { Plymouth* }\end{array}$ & $\begin{array}{l}N \\
\text { follo } \\
20 \\
-\end{array}$ & $\begin{array}{l}\text { o. of } \\
\text { wing } \\
21 \\
2\end{array}$ & $\begin{array}{l}\text { flshe } \\
7 \text { ler } \\
22 \\
23\end{array}$ & $\begin{array}{l}\text { ez in } \\
\text { ngth } \\
23 \\
8\end{array}$ & $\begin{array}{l}\text { each } \\
\text { grou } \\
24 \\
1\end{array}$ & $\begin{array}{l}\text { of th } \\
\text { ips }(c \\
25 \\
-\end{array}$ & $\begin{array}{l}\text { he } \\
\text { (cm.). } \\
26 \\
-\end{array}$ & $\begin{array}{l}\text { Total } \\
\text { No. } \\
34\end{array}$ & $\begin{array}{l}\text { Average } \\
\text { length. } \\
\text { cm. } \\
22 \cdot 7\end{array}$ & $\begin{array}{l}\text { Year. } \\
\text { class. } \\
1922\end{array}$ \\
\hline & $\begin{array}{l}\text { Oct. } 19 \text { th, } 1925 \\
\text { Nov. 10th, } 1925 \\
\text { Dec. 1st, } 1925\end{array}$ & $\begin{array}{l}\text { Brighton } \\
\text { Brighton } \\
\text { Brighton }\end{array}$ & $\begin{array}{l}- \\
-\end{array}$ & $\begin{array}{r}8 \\
3 \\
11\end{array}$ & $\begin{array}{r}5 \\
5 \\
12\end{array}$ & $\begin{array}{l}1 \\
2 \\
7\end{array}$ & $\overline{2}$ & $\begin{array}{l}- \\
-\end{array}$ & $\begin{array}{l}1 \\
-\end{array}$ & $\begin{array}{l}15 \\
12 \\
33\end{array}$ & $\begin{array}{l}22 \cdot 3 \\
22 \cdot 75 \\
22 \cdot 6\end{array}$ & $\begin{array}{l}1923 \\
1923 \\
1923\end{array}$ \\
\hline & $\begin{array}{l}\text { Nov. 1st, } 1926 \\
\text { Nov. 4th, } 1926 \\
\text { Dec. 2nd, } 1926 \\
\text { Dec. } 10 \text { th, } 1926\end{array}$ & $\begin{array}{l}\text { Brighton } \\
\text { Brighton } \\
\text { Brighton } \\
\text { Hastings }\end{array}$ & $\begin{array}{l}- \\
-\end{array}$ & $\begin{array}{l}4 \\
4 \\
3 \\
-\end{array}$ & $\begin{array}{r}9 \\
13 \\
6 \\
13\end{array}$ & $\begin{array}{l}7 \\
6 \\
4 \\
5\end{array}$ & $\begin{array}{l}2 \\
1 \\
\frac{2}{2}\end{array}$ & $\begin{array}{l}- \\
- \\
-\end{array}$ & $\begin{array}{l}\overline{-} \\
\overline{-}\end{array}$ & $\begin{array}{l}22 \\
24 \\
13 \\
20\end{array}$ & $\begin{array}{l}22 \cdot 8 \\
22 \cdot 7 \\
22 \cdot 6 \\
22 \cdot 95\end{array}$ & $\begin{array}{l}1924 \\
1924 \\
1924 \\
1924\end{array}$ \\
\hline & Nov. 1st, 1927 & Brighton & - & 1 & 15 & 39 & 14 & 1 & - & 70 & $23 \cdot 5$ & 1925 \\
\hline \multirow{3}{*}{ 4-zoned 4-ringed \{} & Dec. 9th, 1924 & Piymouth* & - & - & 6 & 9 & 9 & - & - & 24 & $23 \cdot 6$ & 1921 \\
\hline & $\begin{array}{l}\text { Oct. } 19 \text { th, } 1925 \\
\text { Nov. 10th, } 1925 \\
\text { Dec. 1st, } 1925 \\
\end{array}$ & $\begin{array}{l}\text { Brighton } \\
\text { Brighton } \\
\text { Brighton }\end{array}$ & $\frac{\overline{1}}{-}$ & $\begin{array}{l}8 \\
2 \\
-\end{array}$ & $\begin{array}{r}21 \\
15 \\
9\end{array}$ & $\begin{array}{l}29 \\
29 \\
10\end{array}$ & $\begin{array}{r}10 \\
9 \\
6 \\
\end{array}$ & $\begin{array}{l}\overline{2} \\
1\end{array}$ & $\begin{array}{l}\overline{2} \\
-\end{array}$ & $\begin{array}{l}68 \\
60 \\
26\end{array}$ & $\begin{array}{l}23 \cdot 1 \\
23 \cdot 4 \\
23 \cdot 5\end{array}$ & $\begin{array}{l}1922 \\
1922 \\
1922 \\
\end{array}$ \\
\hline & $\begin{array}{l}\text { Nov. 1st, } 1926 \\
\text { Nov. 4th, } 1926 \\
\text { Dec. 2nd, } 1926 \\
\text { Dec. 10th, } 1926\end{array}$ & $\begin{array}{l}\text { Brighton } \\
\text { Brighton } \\
\text { Brighton } \\
\text { Hastings }\end{array}$ & $\begin{array}{l}\overline{-} \\
\overline{-}\end{array}$ & $\begin{array}{l}- \\
- \\
-\end{array}$ & $\begin{array}{r}11 \\
8 \\
5 \\
1\end{array}$ & $\begin{array}{l}23 \\
23 \\
30 \\
23\end{array}$ & $\begin{array}{l}16 \\
22 \\
22 \\
28\end{array}$ & $\begin{array}{l}3 \\
2 \\
3 \\
6\end{array}$ & $\begin{array}{l}- \\
\overline{1} \\
\overline{1}\end{array}$ & $\begin{array}{l}53 \\
55 \\
60 \\
59\end{array}$ & $\begin{array}{l}23 \cdot 7 \\
23 \cdot 8 \\
23 \cdot 9 \\
24 \cdot 2\end{array}$ & $\begin{array}{l}1923 \\
1923 \\
1923 \\
1923\end{array}$ \\
\hline & Nov. 1st, 1927 & $\begin{array}{l}\text { Brighton } \\
\text { * Caugl }\end{array}$ & - & - & yen. & 8 & 3 & 2 & - & 15 & 23.8 & 1924 \\
\hline
\end{tabular}

It is sufficient at this stage to point out that the average lengths shown above are markedly less than the corresponding values for herrings landed at Plymouth (cf. Ford, 1, Part III, p. 293). 


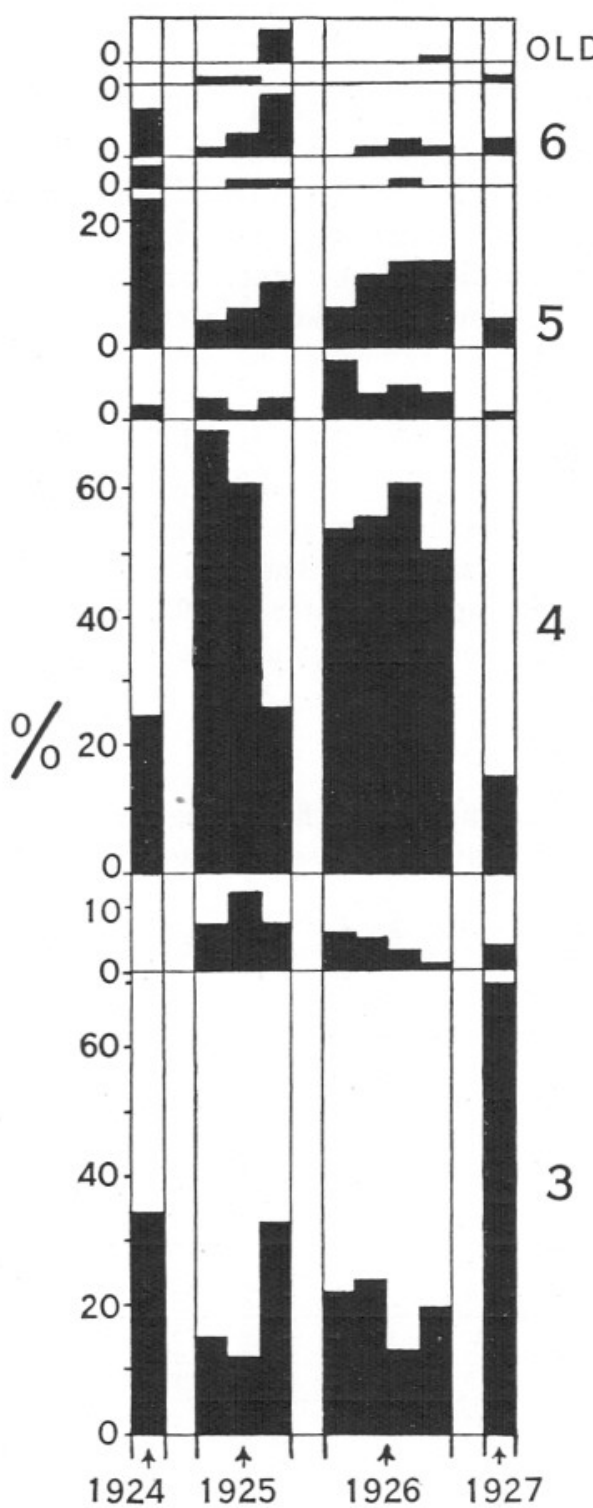

Fig. 1.-Age composition of samples from off Sussex coast.

Samples percentages are shown as small vertical blocks. The age classes are as follows :-

3 . 3-zoned 3-ringed.

4 . 4-zoned 4-ringed.

5 . 5-zoned 5-ringed.

6 . 6-zoned 6-ringed.

old . . Zones and rings exceeding 6 . The "interval " classes are 3 or 4,4 or 5 , etc.

\section{Length at Formation of First}

Winter-ring.

In the consideration of herrings taken in the Sussex district, data on the length $\left(l_{1}\right)$ at the formation of the first winter-ring are of particular interest, for such information bears directly upon the question of the degree to which the herring stock is indigenous to the English Channel or is augmented from the Southern North Sea. Moreover, as already emphasized in previous reports, precise knowledge of the magnitude and variation of $l_{1}$ is essential if reliable comparisons of growth are to be made. In Tables III and IV on pages 40,41 , values of $l_{1}$ for 3-zoned 3-ringed fishes and 4-zoned 4-ringed fishes are given. The variation, not only from individual to individual, but from sample to sample, is seen to be large in both series. Under such circumstances there appears little justification for attaching great significance to the absolute value of any form of average.

We will examine the data for the 4-zoned 4-ringed fishes. It is evident that the dispersion of the variates over the total range of variation in $l_{1}$ differs appreciably from season to season. The samples of 1925 are distinct from those of other years in that they contain a high proportion of herrings with $l_{1}$ say from $7 \mathrm{~cm}$. to $9 \mathrm{~cm}$. Now it will be recalled that Hodgson (2, p. 16) recognises a "Southern North Sea Type" of 
herring $\left(\mathrm{l}_{1}=8 \mathrm{~cm}\right.$.), which he regards as distinct from "Channel" herrings $\left(\mathrm{l}_{1}=12 \mathrm{~cm}\right.$.). In January, 1926, from his study of the scales of herrings landed at Boulogne (vide Hodgson, 3, p. 342), Hodgson concluded that North Sea fish of his Southern Type were spawning along with Channel fish at that time. Under this hypothesis of two distinct types of herrings in the eastern section of the English Channel, it is conceivable that, periodically, Southern North Sea Type herrings may visit the English side of the Channel as well as the French. Such, for instance, would account for the high proportion of fish with $\mathrm{l}_{1}$ from $7 \mathrm{~cm}$. to $9 \mathrm{~cm}$., in the above Sussex samples during the winter of 1925. Possibly, in other years, this phenomenon is not so marked in extent. A yearly variation in the proportions of the two types would also account for the seasonal differences in dispersion of the variates over the total range in $l_{1}$ among the samples taken. This question will, however, receive further attention at a later stage.

\section{Growth subsequent to Formation of First Winter-ring.}

In Part I (Ford, 1, p. 249) it was shown that the data on the growth of 4-zoned 4-ringed fishes caught off the Sussex coast during the seasons 1924 to 1926 could be summarised in the form of five mathematical equations :-

$$
\begin{aligned}
& l_{2}=\cdot 59 l_{1}+11 \cdot 70 \ldots \ldots \ldots \\
& l_{3}=\cdot 504 l_{2}+12 \cdot 80 \ldots \ldots \ldots \\
& l_{4}=\cdot 774 l_{3}+6 \cdot 71 \ldots \ldots \ldots \\
& l_{3}=\cdot 277 l_{1}+18 \cdot 92 \ldots \ldots \ldots \\
& l_{4}=\cdot 221 l_{1}+21 \cdot 28 \ldots \ldots \ldots
\end{aligned}
$$

An illustration was also given of the way these equations might be used to compare the growth of the Sussex fishes with that of fishes of a similar age from a different locality. In the present instance, they will be utilised to compare the data with the growth-characters of Hodgson's "Southern North Sea Type." In 2, page 16, Hodgson shows diagrammatically the size at each year, which is :-

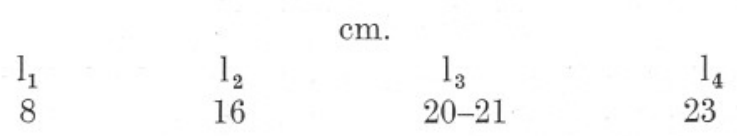

Using equation (1) above, we find the value of $l_{2}$ for $l_{1}$ of $8 \mathrm{~cm}$. :-

$$
\begin{aligned}
\mathrm{l}_{2} & =\cdot 59 \mathrm{l}_{1}+11 \cdot 70 \ldots \ldots(1) \\
& =\cdot 59(8)+11 \cdot 70 \ldots \ldots(2) \\
& =16 \cdot 4 \mathrm{~cm} . \text { (compare with Hodgson's } \mathrm{l}_{2}=16 \mathrm{~cm} \text {.). }
\end{aligned}
$$


Using equation (4) above, we find the value of $l_{3}$ for $l_{1}$ of $8 \mathrm{~cm}$. :-

$$
\begin{aligned}
\mathrm{l}_{3} & =\cdot 277 \mathrm{l}_{1}+18 \cdot 92 \ldots \ldots(4) \\
& =\cdot 277(8)+18 \cdot 92 \\
& \left.=21 \cdot 1 \mathrm{~cm} . \text { (compare with Hodgson's } \mathrm{l}_{3}=20-21 \mathrm{~cm} .\right) .
\end{aligned}
$$

Using equation (5) above, we find the value of $\mathrm{l}_{4}$ for $\mathrm{l}_{1}$ of $8 \mathrm{~cm}$. :-

$$
\begin{aligned}
l_{4} & =\cdot 221 l_{1}+21 \cdot 28 \ldots \ldots \ldots(5) \\
& =\cdot 221(8)+21 \cdot 28 \\
& =23 \cdot 0\left(\text { compare with Hodgson's } l_{4}=23 \mathrm{~cm} .\right) .
\end{aligned}
$$

These results are sufficiently in accord to say that fishes with $l_{1}=8 \mathrm{~cm}$. caught off the Sussex coast are remarkably similar in growth to those on which Hodgson based his "Southern North Sea Type."

Let us now consider Hodgson's " Channel Type." A total of 36 4-zoned fishes of length $24 \mathrm{~cm}$. examined by him from Brighton on January 4th, 1924 , was found to show an average $l_{1}$ of $12 \cdot 34 \mathrm{~cm}$. Using equation (5) above, we find the value of $l_{4}$ for $l_{1}$ of $12 \cdot 34 \mathrm{~cm}$. :-

$$
\begin{aligned}
\mathrm{l}_{4} & =\cdot 2211_{1}+21 \cdot 28 \ldots \ldots \ldots(5) \\
& =\cdot 221(12 \cdot 34)+21 \cdot 28 \\
& \left.=24 \cdot 0 \mathrm{~cm} . \text { (compare with Hodgson's } \mathrm{l}_{4}=24 \cdot 0 \mathrm{~cm} .\right) .
\end{aligned}
$$

This provides reason for arguing that fishes with $\mathrm{l}_{1}$ about $12 \mathrm{~cm}$. caught off the Sussex coast resemble those of the "Channel Type" of Hodgson. Thus both Southern Northern Sea Type and Channel Type are satisfied by the same growth equations. In other words, so far as growth is concerned, the initial difference between the values of $l_{1}$ is, of itself, sufficient to account for the subsequent differences between the values of $\mathrm{l}_{2}, \mathrm{l}_{3}$, and $\mathrm{l}_{4}$ in the two types. Expressing this in another way, it may be said that the particular growth conditions which induce $8 \mathrm{~cm}$. whitebait to develop into 4-zoned 4-ringed fishes of the Southern North Sea Type would induce $12.35 \mathrm{~cm}$. whitebait to develop into 4-zoned 4-ringed fishes of the Channel Type; there is no necessity to assume any difference between growth conditions.

\section{Movements of Shoals.}

It is convenient to discuss the movements of the shoals by commencing the migratory cycle with the fish on the local grounds in the winter. We have seen that, here, they are "full " fishes approaching maturity. We may, therefore, assume that they will eventually move off to spawn. The observations of Wallace (5) and Hodgson (3) indicate a spawning region in the neighbourhood of Cap d'Antifer, this locality being not unduly remote from the Sussex coast. Fishes actually spawning were obtained by 
Hodgson (3) in January, 1926. After spawning, however, facts are less clear. If we follow le Gall (4) we shall now draw a distinction between the Channel Type and the Southern North Sea Type of fish ; we shall contend that the latter retire into the North Sea while the former remain within the English Channel. Regarding this phase, some interest is attached to a sample of fishes caught off Brighton on May 22nd, 1926. Of a total of 65 there were 32 showing 5-zones and 4-rings to the scale. These 32 individuals, then, had obviously been 4-zoned 4-ringed fishes in the winter of 1925, and at the time of capture had commenced their 5th summer zone. In length they varied from $22 \mathrm{~cm}$. to $25 \mathrm{~cm}$, about a mean of $23.9 \mathrm{~cm}$., and their values of $l_{2}, l_{3}$, and $l_{4}$ closely approximated to those of the Southern North Sea Type. Thus, while we may freely admit the possibility of an interchange of fish between the North Sea and the English Channel, as le Gall suggests, we must also admit that fishes of the Southern North Sea Type of growth can and do remain within the Channel after spawning.

We have now to consider the nature of the shoals which arrive off the coast of Sussex in the winter. To what extent are they composed of stock which had previously visited the area, and from whence comes any new stock? We have seen that each season, the bulk of the fishes caught are either 3-zoned 3-ringed or 4-zoned 4-ringed individuals. Thus, the 4-zoned 4-ringed fish do not subsequently return, or at least, are not captured. The 3-zoned 3-ringed ones, may, however, do so in the next year constituting the 4-zoned 4-ringed fishes of the new season. In addition, there must certainly be an important influx of new stock. It is possible that 4-zoned 4-ringed fishes which have never previously visited the area may arrive, conceivably in part from the North Sea, while undoubtedly 3-zoned 3-ringed individuals approaching first maturity will make their appearance for the first time.

\section{Racial Considerations.}

As stated in Parts I and II, the methods adopted in the present series of studies enable the worker to investigate growth and migrations without thought of "races" or "racial composition"; at any rate, in the initial stages. Probably no better illustration could be given of the great practical difficulties to be faced by an investigator who sets out to determine the races represented, than that afforded by the situation in the area under consideration. Here, in brief, are the facts as they are known at present:-

(A) Off the Sussex coast during the winter.

There is a mixed assemblage of "full" fishes which, judging by the values of $l_{1}$ deduced from scale measurements, had grown from "whitebait "varying from $5 \mathrm{~cm}$. to $17 \mathrm{~cm}$. in length. There is no uniformity from 
sample to sample or from season to season as regards the proportions of the fishes from the different whitebait; sometimes those derived from small whitebait are the more numerous, at other times, those derived from the larger.

(B) On the spawning-ground in the neighbourhood of Cap d'Antifer.

Here, again, there is a mixed assemblage of fishes actually spawning together (Hodgson, 3). The scale-characters of the spawners are similar to those of the fishes mentioned under (A) above. The larvæ resulting from this spawning may or may not be direct crosses between fishes with small $l_{1}$ and those with large $l_{1}$. The larvæ themselves may be transported by water movements through the Straits of Dover into the North Sea, and thence to the Thames Estuary where they enter into the composition of the shoals of whitebait along with young herrings from the North Sea itself (Wallace, 5, p. 7).

(C) Off the Sussex coast during the summer.

Shoals of herrings comparable in growth with those of (A) and (B) above may be met with, still providing evidence of mixture.

In view of these facts it would seem essential that in accumulating statistical material for racial analysis, the age, total length, magnitude of $l_{1}$ and stage of maturity would all have to be taken into account. Furthermore, if the " race" data are to be statistically reliable, the number of individuals in each statistical class must be fairly large. This means that the original samples of the mixed catch, taken at random, must be very large. An instance may be given from present records. A random sample of 100 fishes taken off Brighton on November 10th, 1925, included 60 of age 4-zone 4-rings. Of these 60 , there were 29 having a total length of $23 \mathrm{~cm}$. The values of $l_{1}$ for these 29 individuals were :-

$\begin{array}{cccccc}7.5 & 8.5 & 9 \cdot 5 & 10 \cdot 5 & 11 \cdot 5 & 12 \cdot 5 \\ 2 & 12 & 8 & 4 & - & 3\end{array}$

Thus, if we wished to obtain reliable data (e.g. on Average No. of Vertebræ or No. of Keeled Scales) concerning 4-zoned 4-ringed fishes of length $23 \mathrm{~cm}$., for different values of $l_{1}$, the original random sample would need to be many times larger than the one actually taken. To complete the amount of additional routine work occasioned by thus largely increasing the size of the random sample, especially when sampling itself must be frequent, would be beyond the capacity of a single investigator. 


\section{Herrings caught in the Great West Bay.}

The herrings landed at Brixham during the winter form an interesting study, but care must be taken to ascertain the particular locality from which the fishes have been landed. In some seasons the shoals upon which the Plymouth steam fishery is being concentrated are located well up Channel off Start Point and a certain number of East Country steamers may elect temporarily to use Brixham as their port of landing. Apart from this, however, drift and standing nets are every year worked still farther to the eastward in the Great West Bay, and it is concerning these fish that information is given below. Between November, 1925, and January, 1927, eight samples were sent to Plymouth from Brixham, where they were submitted to the usual routine examination.

\section{Condition of Gonads (Roes and Milts).}

The following is a summary of the data on the degree of maturity of the gonads :-

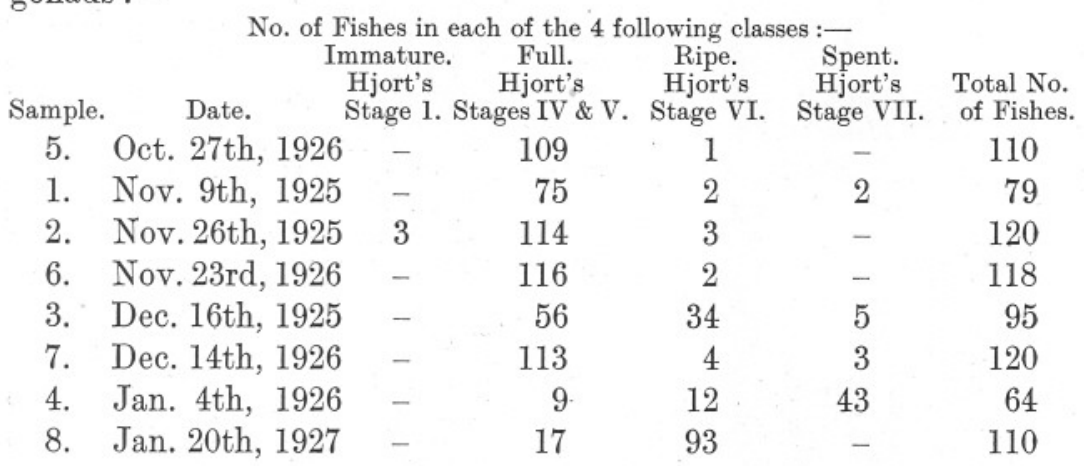

These samples indicate that we have to deal with December and January spawning fishes. Sample 8 , of which about $90 \%$ were fully mature $\delta$ and + fishes, was from a total catch of 20 crans made by a motordrifter off Exmouth, so that it is reasonable to suspect that actual spawning occurred at no great distance from this locality. As in the case of the Sussex herrings, the youngest fishes (3-zoned 3-ringed) gave evidence that they would spawn in their third winter of life in the scaled condition.

\section{Average Length.}

It will be seen from the values of $Q_{1}, Q_{2}$, and $Q_{3}$ given in Table $V$ on page 41 , that there are appreciable differences in length distribution between samples. Thus, on November 26th, 1925, the middle 50\% $\left(Q_{3}-Q_{1}\right)$ included fishes of the $22 \mathrm{~cm} ., 23 \mathrm{~cm}$., and $24 \mathrm{~cm}$. length groups, 
whereas on January 4th, 1926, it comprised those of the $25 \mathrm{~cm} ., 26 \mathrm{~cm}$., and $27 \mathrm{~cm}$. groups. Sample 3, taken on December 16th, 1925, on the other hand, is bimodal as regards length. No very useful purpose, there-

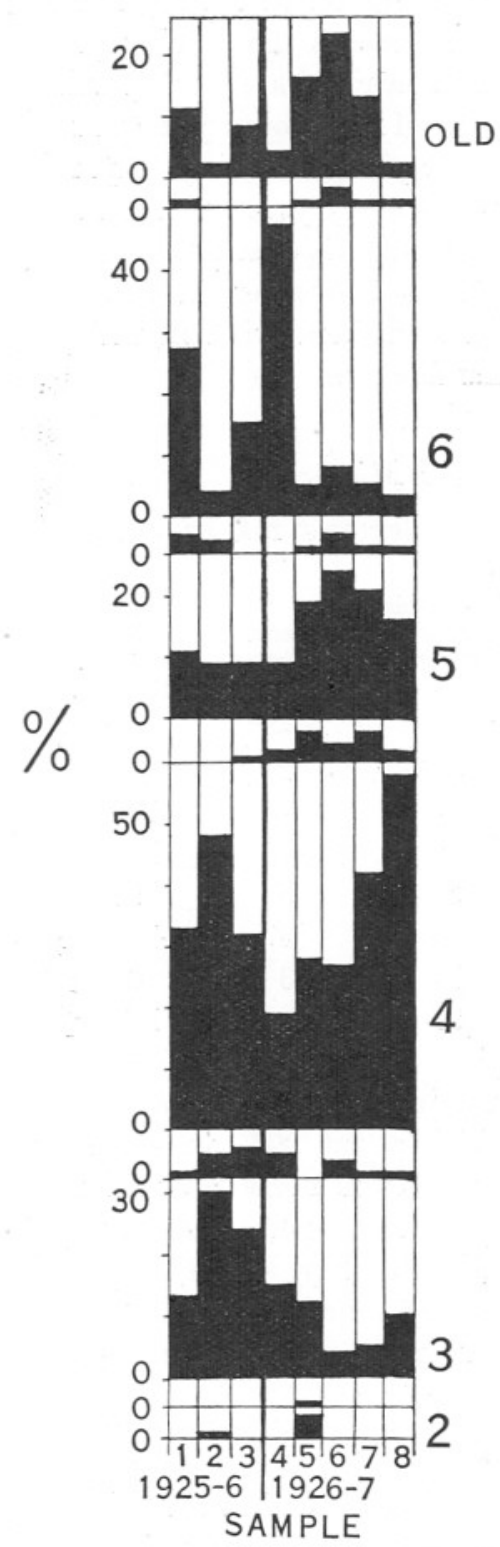

Fig. 2.-Age composition of samples from Great West Bay.

Details as in Fig. 1 (page 28). fore, is served by conducting a more detailed analysis of the raw length data as they stand. There is, however, one point of interest which was referred to in Part III (1, p. 287). It was there shown that in the Plymouth samples there was a tendency for the average length to be lower towards the eastwards. (i.e. from Plymouth towards Start Point). The present series of samples was taken from catches made in waters still farther to the eastward, and it will be observed that there is a further depression in the lower quartile length $\left(Q_{1}\right)$. That is to say, a larger proportion of smaller fishes is likely to be landed from the Great West Bay than from the area covered by the Plymouth fishery. It is thus possible that in the intermediate waters to the eastward of Plymouth some overlap of fish-population may occur.

\section{Age Composition of Samples.}

Estimates of age from scale-readings, expressed in the form of percentages, are given in Table VI on page 42, and recorded graphically in Fig. 2.

In the first place it will be noted that the 4-zoned 4-ringed class was always well represented; in 7 of the total of 8 samples it was actually the dominant constituent. The samples of the season 1925-26 also showed an appreciable percentage of 3-zoned 3-ringed fishes. In this heavy proportion of young fishes, then, the situation resembles that experienced off the Sussex coast (vide p. 27).

Unlike the Brighton and Hastings samples, however, the present ones 
include an appreciable percentage of individuals older than 4-zones 4-rings. Of these older individuals, those of the year-class 1920, as 6-zoned 6-ringed fishes, were important during the season 1925-26, and again as 7-zoned 7-ringed fishes in the following season, 1926-27. On the other hand, fishes of the 1921 class were scarce either as 5-zoned 5-ringed in 1925-26 or as 6-zoned 6-ringed in 1926-27. In these respects, the situation is reminiscent of Plymouth during the corresponding period (vide Ford, 1, Part III, p. 289).

The contribution each season made by the year-classes concerned is shown in convenient summary form below :-

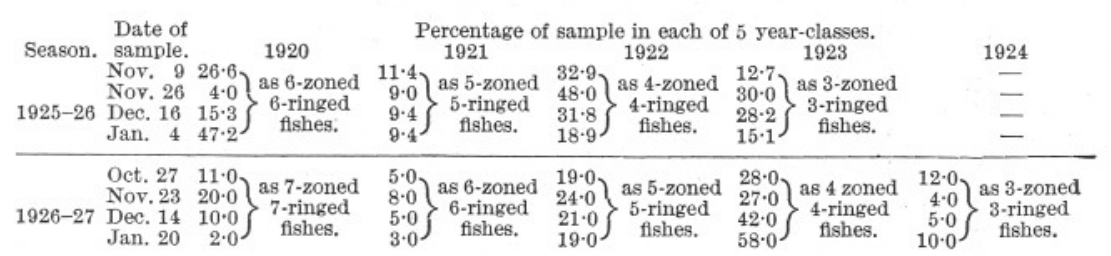

In Part III (Ford, 1, p. 291), in summarising the evidence to be drawn from the results of age-estimations on Plymouth fishes during the season 1926-27, the following was stated: “. . . that the 1920 class showed definite signs of a decline in intensity, and that the 1921 class gave no signs that it would ever become important, while of the younger classes, that of 1923 was the most promising."

An examination of the data summarised in the table above shows that this might equally well be written concerning the samples from the Great West Bay.

\section{Length for Age.}

Fishes of the same age differ so much in total length that little practical significance can be attached to the average length calculated from the lumped sample data throughout one season for a given year-class. Interesting evidence, however, is to be obtained from the data for individual samples :-

\section{3-zoned 3-RINGed Fishes.}

\begin{tabular}{lcrrrrrrrrrrr} 
& \multicolumn{1}{c}{ So. of Fishes in each of 8 Length groups (cm.). Total } & Year- \\
Season. & Date. & 20 & 21 & 22 & 23 & 24 & 25 & 26 & 27 & No. & class. \\
& Nov. 9 & - & - & 1 & 1 & 1 & 3 & 2 & 2 & 10 & \\
$1925-26$ & Nov. 26 & 2 & 2 & 12 & 8 & 4 & 1 & 1 & - & 30 & 1923 \\
& Dec. 16 & - & 4 & 7 & 10 & 2 & 1 & - & - & 24 & \\
& Jan. 4 & - & - & 3 & - & - & 1 & 4 & - & 8 & \\
& & & & & & & & & & & & \\
$1926-27$ & Oct. 27 & - & - & 3 & 4 & 1 & 1 & 2 & 1 & 12 & \\
& Nov. 26 & - & - & - & - & - & 2 & 1 & 1 & 4 & 1924 \\
& Dec. 16 & - & - & 1 & 1 & - & - & 3 & - & 5 & \\
& Jan. 20 & - & 1 & 2 & 4 & 1 & 2 & - & - & 10 &
\end{tabular}


It is seen that there is a tendency for the individuals to group themselves in two parts of the total range in length, viz. in the 22 and $23 \mathrm{~cm}$. groups and again in the 25 and $26 \mathrm{~cm}$. groups. This is instructive, for if we turn to the Sussex samples (p. 27) we see that the 3-zoned 3 -ringed fishes largely fall into the $22 \mathrm{~cm}$. and $23 \mathrm{~cm}$. length groups; on the other hand, if we refer to the Plymouth samples of 1926-27 (Ford, 1, Part III, p. 293) we see that the 3-zoned 3-ringed fishes largely fall into the 25 and $26 \mathrm{~cm}$. length groups.

\section{4-zoned 4-ringed Fishes.}

\begin{tabular}{|c|c|c|c|c|c|c|c|c|c|c|c|c|}
\hline \multirow[b]{2}{*}{ Season. } & & \multicolumn{5}{|c|}{ No. of Fishes in each of 9} & \multicolumn{4}{|c|}{ Length groups (cm.). } & Total & \multirow{2}{*}{$\begin{array}{l}\text { Year- } \\
\text { class. }\end{array}$} \\
\hline & Date. & 21 & 22 & 23 & 24 & 25 & 26 & 27 & 28 & 29 & No. & \\
\hline \multirow{4}{*}{$1925-26$} & Nov. 9 & - & 2 & 1 & 5 & 4 & 8 & 5 & - & 1 & 26 & \multirow{4}{*}{1922} \\
\hline & Nov. 26 & 1 & 11 & 15 & 13 & 4 & 4 & - & - & - & 48 & \\
\hline & Dec. 16 & - & 11 & 5 & 3 & 4 & 3 & 1 & - & - & 27 & \\
\hline & Jan. 4 & - & - & 1 & 2 & 4 & 2 & 1 & - & - & 10 & \\
\hline \multirow{4}{*}{$1926-27$} & Oct. 27 & - & 1 & 1 & 20 & 5 & 1 & - & - & - & 28 & \multirow{4}{*}{1923} \\
\hline & Nov. 26 & - & - & 1 & 13 & 5 & 7 & 1 & - & - & 27 & \\
\hline & Dec. 16 & - & - & 8 & 16 & 14 & 3 & 1 & - & - & 42 & \\
\hline & Jan. 20 & - & 2 & 13 & 33 & 9 & 1 & - & - & - & 58 & \\
\hline
\end{tabular}

In this age-group, fishes group themselves in different parts of the total length range in different samples. Here again it is interesting to compare the data with those from Sussex and Plymouth. In the Brixham sample of November 26th, 1925, of a total of 48 individuals, 39 fall into the 22, 23 , and $24 \mathrm{~cm}$. length groups. This compares favourably with a sample of sixty 4-zoned 4-ringed fishes taken off Brighton on November 10th, 1925 , of which 53 fall into the same length groups. In contrast with this, it is to be noted that during the season 1925-26 at Plymouth, 4-zoned 4-ringed fishes grouped themselves largely in the 25, 26, and $27 \mathrm{~cm}$. groups, whereas here in the Great West Bay samples, fishes of a similar age exceeding $26 \mathrm{~cm}$. in length are few in number.

\section{5-Zoned 5-RInged Fishes.}

As already stated above, fishes of this age (1921 year-class) were relatively unimportant during the season 1925-26. In the following season, however, when the members of the 1922 year-class had become 5-zoned 5-ringed fishes, the proportion was appreciable. The lengthdistribution was as follows :-

\begin{tabular}{llrrrrrrrr} 
& \multicolumn{1}{c}{ No. of Fishes in each of 6} & Length groups (cm.). & Total & Year- \\
Season. & Date. & 23 & 24 & 25 & 26 & 27 & 28 & No. & class. \\
& Oct. 27 & 3 & 6 & 6 & 1 & 3 & - & 19 & \\
$1926-27$ & Nov. 26 & - & 2 & 12 & 3 & 5 & 2 & 24 & 1922 \\
& Dec. 16 & 1 & 3 & 9 & 5 & 3 & - & 21 & \\
& Jan. 20 & 2 & 6 & 9 & 2 & - & - & 19 &
\end{tabular}


Compared with the Plymouth fishes of the same year-class during the same season (vide Ford, 1, Part III, p. 293) the above are distributed over a lower part of the length-range.

\section{6-ZONED 6-RINGED Fishes.}

Members of the 1920 year-class as 6-zoned 6-ringed fishes were of considerable importance in three of the four samples taken during the season of 1925-26. Data on length are as follows :-

\begin{tabular}{lcrrrrrrrrr} 
& \multicolumn{1}{c}{ No. of Fishes in each of 7 Length groups (cm.). } & Total & Year- \\
Season. & Date. & 25 & 26 & 27 & 28 & 29 & 30 & 31 & No. & class. \\
& Nov. 9 & 1 & 3 & 10 & 3 & 2 & - & 1 & 21 & \\
$1925-26$ & Nov. 26 & - & 1 & 3 & - & - & - & - & 4 & 1920 \\
& Dec. 16 & 2 & 5 & 4 & 1 & 1 & - & - & 13 & \\
& Jan. 4 & 3 & 6 & 5 & 7 & 4 & - & - & 25 &
\end{tabular}

The fishes of the 1920 year-class caught during the season 1925-26 at Plymouth (vide Ford, 1, Part III, p. 293) were largely grouped in the $26,27,28$, and $29 \mathrm{~cm}$. length groups, and of an average length of $27 \cdot 9 \mathrm{~cm}$.

\section{7-ZONED 7-RINGed Fishes.}

During the season 1926-27, a fair proportion of the 1920 class, now as 7 -zoned 7 -ringed individuals, was present in the samples :-

\begin{tabular}{lrrrrrrr} 
& \multicolumn{7}{c}{$\begin{array}{l}\text { No. of Fishes in each of } \\
\text { 4 Length groups (cm.). }\end{array}$} \\
Season. & Date. & 25 & 26 & 27 & 28 & Notal & Year- \\
& Oct. 27 & - & 1 & 6 & 4 & 11 & \\
$1926-27$ & Nov. 26 & - & 8 & 10 & 2 & 20 & 1920 \\
& Dec. 16 & 3 & 7 & - & - & 10 & \\
& Jan. 20 & - & 2 & - & - & 2 &
\end{tabular}

The above are certainly distributed over a lower part of the length range than corresponding fishes landed at Plymouth.

From the foregoing considerations of length for age it seems permissible to draw two conclusions concerning the herrings landed from the Great West Bay :-

(a) Of the fishes of the younger age-groups (3-zoned 3-ringed and 4-zoned 4-ringed) many are of a length similar to that for fishes of corresponding age caught off the Sussex coast.

(b) Herrings of the older age-groups (5-zoned 5-ringed and older) are generally distributed over a lower part of the total length range than similar aged fishes taken in Plymouth waters during the same period. 


\section{Length at Formation of First Winter-ring $\left(\mathrm{l}_{1}\right)$.}

In view of the relative importance in the catches of 4-zoned 4-ringed fishes, the lengths $l_{1}, l_{2}$, and $l_{3}$ have been calculated from scale-measurements. The data on $l_{1}$ for each sample are as follows :-

\section{4-ZONED 4-RINGed Fishes.}

\begin{tabular}{|c|c|c|c|c|c|c|c|c|c|c|c|c|c|c|c|}
\hline Searon. & Date & 6.5 & $\underset{7 \cdot 5}{L}$ & ${ }_{8 \cdot 5}^{C}$ & $\begin{array}{l}\text { tral } \\
9 \cdot 5\end{array}$ & $\begin{array}{l}\text { value } \\
10.5\end{array}$ & $\begin{array}{l}\text { of } 12 \\
11.5\end{array}$ & $\begin{array}{l}\text { class } \\
12 \cdot 5\end{array}$ & $\begin{array}{l}\text { es }(\mathrm{cn} \\
13 \cdot 5\end{array}$ & 1.). & $15 \cdot 5$ & 16.5 & $17 \cdot 5$ & $\begin{array}{l}\text { Total No. } \\
\text { of fishes. }\end{array}$ & $\begin{array}{l}\text { Year- } \\
\text { class. }\end{array}$ \\
\hline \multirow[t]{5}{*}{$1925-26$} & Nov. 9 & - & 2 & 3 & 1 & 4 & 1 & 2 & 6 & 2 & 2 & 1 & 1 & 25 & \\
\hline & Nov. 26 & 2 & 5 & 13 & 10 & 4 & 4 & - & 2 & 1 & - & - & - & 41 & 1922 \\
\hline & Dec. 16 & 1 & 2 & 9 & 1 & 2 & 1 & 1 & 3 & 1 & - & - & - & 21 & \\
\hline & Jan. 4 & - & - & 2 & 1 & 1 & 3 & 1 & 1 & 1 & - & - & - & 10 & \\
\hline & Oct. 27 & - & 2 & 5 & 3 & 2 & 2 & 3 & 5 & 4 & 1 & - & - & 27 & \\
\hline \multirow[t]{3}{*}{$1926-27$} & Nov. 26 & - & - & 2 & 1 & 5 & 2 & 3 & 3 & 5 & 5 & - & 1 & 27 & 1923 \\
\hline & Dec. 16 & - & 1 & - & 3 & 7 & 2 & 7 & 3 & 6 & 7 & 2 & - & 38 & \\
\hline & Jan. 20 & - & - & 2 & 4 & 10 & 5 & 7 & 6 & 8 & 6 & 4 & 1 & 53 & \\
\hline
\end{tabular}

Thus, as has been seen at Brighton and Plymouth, the value of $l_{1}$ for fishes in the Great West Bay varies over a considerable range. The sample of November 26th, 1925, is interesting in that there was an appreciable number of fishes with $l_{1}$ from 7.5 to $9.5 \mathrm{~cm}$. This reminds us of the situation at Brighton. More frequently, however, $l_{1}$ is comparatively large, often exceeding $12.5 \mathrm{~cm}$., and in this respect, the samples are in closer agreement with those of similar-aged fishes landed at Plymouth.

\section{Average Number of Vertebrce.}

Data on the number of vertebræ for herrings of the samples under consideration have already been given in Part II (Ford, 1). If we refer to Fig. 1 on page 274 of that paper, we see that the average number of vertebræ for these Great West Bay fishes is intermediate between that for Plymouth and that for Sussex herrings. This fact is instructive in view of the results of age and growth comparisons described above.

From the results discussed in the preceding pages, then, we see that the herrings landed from the Great West Bay during the winter present an interesting problem for further study. Efforts must be directed towards an understanding of why, on the one hand, there is a measure of similarity to the Sussex fish, and, on the other, to those landed at Plymouth. By a detailed systematic sampling it should be possible to arrive at a fuller knowledge of the migratory cycles of the herrings frequenting the English Channel generally, and, incidentally, therefore, to throw light on these movements as they concern the Plymouth shoals in particular. 


\section{LITERATURE CITED.}

1. Ford, E. Herring Investigations at Plymouth. Parts I, II, and III. Journ. Mar. Biol. Assoc., Vol. XV, Feb., 1928.

2. Hodgson, W. C. Investigations into the Age, Length, and Maturity of the Herring of the Southern North Sea. Part II. Min. Agric. Fish., Fish. Invest., Ser. II, Vol. VIII, No. 5, 1925.

3. Hodgson, W. C. The Herrings of the Eastern Part of the English Channel. Nature, March 6th, 1926.

4. Le GALL, J. Études diverses sur la question du Hareng. Office Scient. Tech. des Pêches Mar., Notes et Rapp., No. 48, 1926.

5. Wallace, W. First Repport on Young Herring in the Southern North Sea and English Channel. Part I. Min. Agric. Fish., Fish. Invest., Ser. II, Vol. VII, No. 4, 1924.

\section{TABLE I.}

\section{Herrings caught off Sussex Coast.}

\begin{tabular}{|c|c|c|c|c|c|c|c|c|}
\hline \multirow[b]{2}{*}{$\begin{array}{l}\text { Sample } \\
\text { No. }\end{array}$} & \multirow[b]{2}{*}{$\begin{array}{c}\text { Date. } \\
1924\end{array}$} & \multirow[b]{2}{*}{$\begin{array}{c}\text { Port of } \\
\text { Landing. }\end{array}$} & \multirow[b]{2}{*}{$\begin{array}{l}\text { Total } \\
\text { No. of } \\
\text { Fishes. }\end{array}$} & \multicolumn{4}{|c|}{ Length Distribution (cm.). } & \multirow{2}{*}{$\begin{array}{l}\text { Upper } \\
\text { Limit. }\end{array}$} \\
\hline & & & & $\begin{array}{l}\text { Lower } \\
\text { Limit. }\end{array}$ & $\begin{array}{c}\text { Lower } \\
\text { Quartile } \\
\text { Q }_{1} \text {. }\end{array}$ & $\begin{array}{c}\text { Median } \\
\mathrm{Q}_{2} .\end{array}$ & $\begin{array}{c}\text { Upper } \\
\text { Quartile } \\
\text { Q }_{3} .\end{array}$ & \\
\hline 1. & $\begin{array}{ll}\text { Dec. } & 9 \\
1925 & \end{array}$ & Plymouth* & 161 & $21 \cdot 5$ & $22 \cdot 6$ & $23 \cdot 6$ & $24 \cdot 7$ & $26 \cdot 5$ \\
\hline 2. & Oct. 19 & Brighton & 128 & $20 \cdot 5$ & $22 \cdot 1$ & $23 \cdot 0$ & $23 \cdot 8$ & $26 \cdot 5$ \\
\hline 3. & Nov. 10 &, & 100 & $20 \cdot 5$ & $22 \cdot 8$ & $23 \cdot 5$ & $24 \cdot 3$ & $27 \cdot 5$ \\
\hline 4. & $\begin{array}{l}\text { Dec. } 1 \\
1926\end{array}$ & , & 118 & $21 \cdot 5$ & $22 \cdot 4$ & $23 \cdot 4$ & $24 \cdot 7$ & $29 \cdot 5$ \\
\hline 5. & Nov. 1 & Brighton & 120 & $21 \cdot 5$ & $22 \cdot 9$ & $23 \cdot 5$ & $24 \cdot 2$ & $26 \cdot 5$ \\
\hline 6. & Nov. 4 & , & 100 & $21 \cdot 5$ & $22 \cdot 9$ & $23 \cdot 6$ & $24 \cdot 3$ & $25 \cdot 5$ \\
\hline 7. & Dec. 2 &, & 100 & $21 \cdot 5$ & $23 \cdot 2$ & $23 \cdot 9$ & $24 \cdot 6$ & $25 \cdot 5$ \\
\hline 8. & $\begin{array}{l}\text { Dec. } 10 \\
1927\end{array}$ & Hastings & 120 & $22 \cdot 5$ & $23 \cdot 2$ & $24 \cdot 0$ & $24 \cdot 6$ & $26 \cdot 5$ \\
\hline 9. & Nov. 1 & Brighton & 102 & $21 \cdot 5$ & $23 \cdot 1$ & $23 \cdot 9$ & $24 \cdot 6$ & $25 \cdot 5$ \\
\hline
\end{tabular}

* This sample was from a steamer landing at Plymouth. Nets were shot off Newhaven on the journey westward to Plymouth fromiLowestoft. 


\section{TABLE II.}

\section{Herrings caught off Sussex Coast.}

PERCENTAGE AGE COMPOSITION (ZONES AND RINGS).

Sample

Date.

$3 \quad 3-4$

$4 \quad 4-5$

5

$5-6$

Older Total Older No. of
than 6. Fish. 1924

1. Dec. $9 \quad 34 \quad-\quad \begin{array}{lllllllll}24 & 2 & 23 & 3 & 7 & - & - & 100\end{array}$ 1925

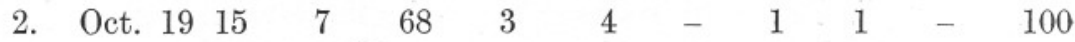

3. Nov. $10 \begin{array}{llllllllll}12 & 12 & 60 & 1 & 6 & 1 & 3 & 1 & - & 100\end{array}$

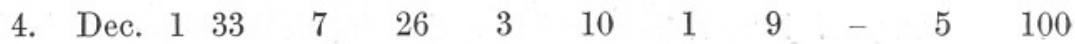
1926

5. Nov. $1 \begin{array}{lllllllllll} & 22 & 6 & 53 & 9 & 6 & - & - & - & - & 100\end{array}$

6. Nov. $4 \begin{array}{lllllllllll}4 & 24 & 5 & 55 & 4 & 11 & - & 1 & - & - & 100\end{array}$

7. Dec. $\begin{array}{lllllllllll}2 & 13 & 3 & 60 & 5 & 13 & 1 & 2 & - & 3 & 100\end{array}$

8. Dec. $10 \begin{array}{lllllllllll} & 20 & 1 & 59 & 4 & 13 & - & 1 & 1 & - & 100\end{array}$ 1927

9. Nov. $1 \begin{array}{lllllllllllll} & 70 & 5 & 15 & 1 & 4 & - & 2 & - & - & 100\end{array}$

\section{TABLE III.}

Herrings caught off Sussex Coast.

3-ZONED 3-RINGED Fishes.

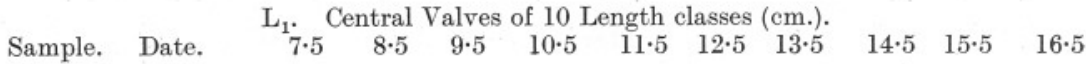
1925

2. Oct. $19-1-3-325-5-$

3. Nov. $10 \quad-\quad-\quad 1 \quad-\quad \begin{array}{lllllll}2 & 3 & 3 & 2 & - & 1\end{array}$

4. Dec. 1 - $\quad-\begin{array}{lllllllll}2 & 3 & 10 & 5 & 4 & 2 & 4 & 1\end{array}$ 1926

5. Nov. 1 -

6. Nov. 4 - $\quad-\begin{array}{llllllllll} & 3 & 3 & 5 & 6 & 4 & 1 & 2 & -\end{array}$

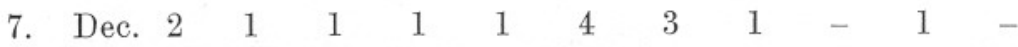

8. Dec. $10 \quad-\quad-\quad \begin{array}{lllllllll}2 & 2 & 3 & 3 & 1 & 3 & 4 & 1\end{array}$ 


\section{TABLE IV.}

\section{Herrings caught off Sussex Coast.}

4-ZONED 4-RINGED FISHES.

$\mathrm{L}_{1}$. Central Valves of 13 Length classes $(\mathrm{cm}$.)

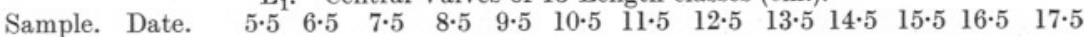
1924

1. Dec. 9 1925

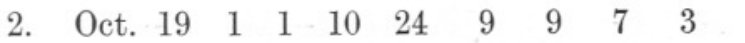

3. Nov. 10 - $\begin{array}{lllllllllllllll} & 1 & 6 & 22 & 13 & 8 & 2 & 5 & - & - & 1 & - & -\end{array}$

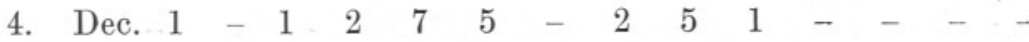
1926

5. Nov. $1-{ }_{1}-\begin{array}{llllllllllll} & 3 & 5 & 5 & 9 & 15 & 4 & 3 & 1 & 2 & - & -\end{array}$

6. Nov. 4 - $\quad-\begin{array}{llllllllllll} & 1 & 3 & 4 & 12 & 15 & 5 & 5 & - & - & - & -\end{array}$

7. Dec. 2 -

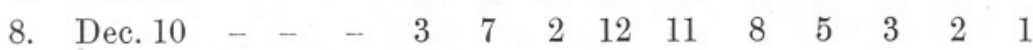

\section{TABLE V.}

Herrings caught in the Great West Bay.

\begin{tabular}{|c|c|c|c|c|c|c|c|}
\hline & & & & LENGTH & ISTRIBUT & ( (см.). & \\
\hline Sample & & $\begin{array}{l}\text { Total } \\
\text { No. of }\end{array}$ & Lower & $\begin{array}{l}\text { Lower } \\
\text { Quartile }\end{array}$ & Median & $\begin{array}{l}\text { Upper } \\
\text { Quartile }\end{array}$ & Upper \\
\hline No. & $\begin{array}{l}\text { Date. } \\
1925\end{array}$ & Fishes. & Limit. & $Q_{1}$ & $\mathrm{Q}_{2}$ & $\mathrm{Q}_{3}$ & Limit. \\
\hline 1. & Nov. 9 & 79 & $22 \cdot 5$ & $25 \cdot 8$ & $27 \cdot 0$ & $28 \cdot 0$ & $31 \cdot 5$ \\
\hline 2. & Nov. 26 & 120 & $20 \cdot 5$ & $22 \cdot 7$ & $23 \cdot 7$ & $24 \cdot 9$ & $28 \cdot 5$ \\
\hline 3. & Dec. 16 & 94 & $21 \cdot 5$ & $22 \cdot 75$ & $24 \cdot 0$ & $26 \cdot 4$ & $29 \cdot 5$ \\
\hline & 1926 & & & & & & \\
\hline 4. & Jan. 4 & 64 & $22 \cdot 5$ & $25 \cdot 1$ & $26 \cdot 6$ & $28 \cdot 1$ & $29 \cdot 5$ \\
\hline 5. & Oct. 27 & 110 & $21 \cdot 5$ & $24 \cdot 2$ & $25 \cdot 1$ & $27 \cdot 1$ & $29 \cdot 5$ \\
\hline 6. & Nov. 23 & 118 & $23 \cdot 5$ & $25 \cdot 3$ & $26 \cdot 2$ & $27 \cdot 2$ & $28 \cdot 5$ \\
\hline 7. & Dec. 14 & 120 & $22 \cdot 5$ & $24 \cdot 5$ & $25 \cdot 4$ & $26 \cdot 1$ & $27 \cdot 5$ \\
\hline & 1927 & & & & & & \\
\hline 8. & Jan. 20 & 110 & $21 \cdot 5$ & $23 \cdot 9$ & $24 \cdot 6$ & $25 \cdot 25$ & $26 \cdot 5$ \\
\hline
\end{tabular}




\section{TABLE VI}

Herrings caught in the Great West Bay.

PERCENTAGE AGE COMPOSITION (ZONES AND RINGS).

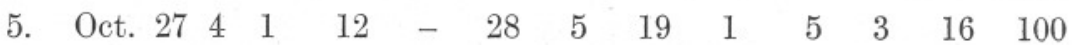

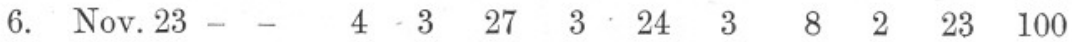

$\begin{array}{llllllllllll}\text { 7. Dec. } 14 \text { - } & - & 5 & 1 & 42 & 5 & 21 & 1 & 5 & 2 & 13 & 100\end{array}$ 1927

8. Jan. 20 - $-\begin{array}{llllllllllll} & 10 & 1 & 58 & 2 & 19 & 1 & 3 & - & 2 & 100\end{array}$ 